Биљана Пајић

Универзитет у Београду

Филолошки факултет
УДК 655.25:004

доИ https://doi.org/10.18485/

melissa.2016.15.1.ch20

\title{
ПРИНЦИП ОТВОРЕНОГ ПРИСТУПА У ОБЛАСТИ АУДИО-ВИЗУЕЛНОГ ПРЕВОЪЕЊА
}

\section{Сажетак}

Принцип отвореног приступа заузима све значајнију улогу у виртуелној култури. Многи научници се залажу за отворен приступ информацијама у науци, а овакав став заузимају и многи други стручњаци. Једна од новијих појава у виртуелном свету је отворен приступ аудио-визуелним преводима, тачније титловима видео-снимака са познатих онлајн-портала. На који начин је омогућен отворени приступ у аудио-визуелном превођењу? Које су његове предности, мане и изазови? Каква је будућност пред оваквим принципом? Ово су питања на која овај рад покушава да да одговоре кроз примере платформи YouTube и Amara.

Кључне речи: аудио-визуелно превођење, отворени приступ, титловање, интернет, Amara, YouTube

Појам отвореног приступа односи се пре свега на научне информације и резултате научних истраживања, а први пут је дефинисан у оквиру Будимпештанске декларације о отвореном приступу 2002. године. ${ }^{1}$ Најсадржајнију дефиницију, међутим, даје Субер у својој књизи „Отворени приступ“, која је, разуме се, бесплатно доступна корисницима интернета широм света.

Суберова дефиниција отвореног приступа представља сажетак дефиниција које су дале Иницијатива о отвореном приступу Будимпеште (Budapest Open Access Initiative, фебруар 2002), компанија Bethesda у Изјави о објављивању у отвореном приступу (Bethesda Statement on Open Access Publishing, јун 2003) и Берлинска декларација о отвореном приступу знању у науци и хуманиори (Berlin Declaration on Open Access to Knowledge in the Sciences and Humanities, октобар 2003).

1 Budapest Open Access Initiative. Budapest Open Access Initiative. 2002. Web. 09.08.2016. 
„Постоје многи нивои и врсте ширег и лакшег приступа [истраживачкој] литератури. Под ,отвореним приступом' овој литератури сматрамо њену слободну доступност јавности на интернету, дозвољавајући било ком кориснику читање, преузимање, умножавање, дистрибуцију, итампање, претраживање или линковање пуног текста ових чланака, њихово индексирање, њихово прослеђивање софтверима у форми података или коришћење у било коју другу легалну сврху, без финансијских, законских или техничких препрека сем оних које подразумевају добијање приступа самој интернет-конекцији. Једино ограничење које се тиче репродукције и дистрибуције и једина улога копирајта у овом погледу треба да дозволи ауторима контролу над интегритетом свог рада и право на одговарајуће признање и цитирање."

Crowdsourcing is the process by which the power of the many can be leveraged to accomplish feats that were once the province of a specialized few.

\section{Jeff Howe}

Термин „краудсорсинг“ (енг. crowdsourcing) према Дуденовом речнику означава делегирање задатака које је одређено предузеће до тада обављало самостално на велики број људи путем интернета. ${ }^{3}$ Оксфордов речник поврх тога напомиње да ова услуга може бити плаћена или пак не. ${ }^{4}$ Осврнућемо се и на интегративну дефиницију краудсорсинга, до које су дошли Естељес-Аролас и Гонзалес-Ладронде-Гевара.

„Краудсорсинг је врста партиципативне онлајн-активности у којој индивидуа, институција, непрофитна организација или компанија групи индивидуа променљивог знања, хетерогености и броја фрлексибилним отвореним позивом нуди волонтерско обављање задатка. Обављање овог задатка променљиве комплекс-

\footnotetext{
2 Suber, Peter. Open Access. Cambridge, London: MIT Press. 2012: 7. Web. 09.08.2016.

3 Duden. Bibliographisches Institut GmbH. 2016. Web. 11.08.2016.

4 Oxford Dictionaries. Oxford University Press. 2016. Web. 11.08.2016.
} 
ности и модуларности, у коме људи учествују доприносећи својим радом, новцем, знањем и/или искуством, увек резултује узајамном коришћу. Корисник добија сатисфакцију потребе дате врсте, било да је у питању економска потреба, друштвено признање, самопоуздање или развој личних вештина, док краудсорсер добија и користи све предности онога чиме је корисник допринео, а чија форма зависи од типа предузете активности. ${ }^{\prime 5}$

\section{YouTube}

Веб-сајт за размену видео-датотека, YouTube, Жан Берже и Џошуа Грин описују као платформу за дистрибуцију која производе комерцијалних медија може начинити популарним међу широком публиком, представљајући притом изазов за промотивни домет који су масовни медији навикли да монополизују, док се иста платформа истовремено користи за садржај који креирају корисници, при чему настају изазови за комерцијалну популарну културу, било да су у питању нови сервиси које корисници креирају, или генеричке форме попут "влогова“ - које пак могу бити прилагођене и искоришћене од стране индустрије традиционалних медија. ${ }^{6}$

Главни фактор који разликује вебкастове од телевизијског програма је, према Данкис, дистрибуција. Телевизијски програм може досегнути ограничен број гледалаца, нпр. локалне вести ће бити доступне само становништву одређене регије. Вебкастови се могу емитовати на глобалном нивоу, а гледаоци их могу гледати вишеструко. Када досегну велики број гледалаца, називају се виралним. ${ }^{7}$

Данкис даје преглед видова коришћења текста на YouTube-y. Према њеном истраживању, интерлингвални и интралингвални текст се користи за титловање, а могуће је наћи видео-снимке са за-

$5 \quad$ Estellés-Arolas, Enrique, and Fernando González-Ladrón-de-Guevara. Towards an integrated crowdsourcing definition. Journal of Information Science XX (X) pp. 1-14. The Author(s) 2012: 9-10. Web. 11.08.2016.

6 Burgess, Jean and Joshua Green. YouTube: online video and participatory culture. Cambridge: Malden. 2009

7 Dankis, Sofia. Subtitling the Internet. An investigation into subtitles for dynamic media. Master thesis. Stockholm: Institute for Interpretation and Translation Studies, Department for Swedish Language and Multilingualism. 2014: 9-10. 
твореним или отвореним титловима. Пиратизовани материјал на YouTube-у, који укључује отворене титлове оригиналног програма, Данкис не сматра титловима за вебкастове, јер су оригинално писани за телевизију и емитовани на њој. Док интерлингвални титлови преводе дијалоге на различите језике, интралингвални титлови се често користе у сврху хумора, али и као појашњење за снимке лошег квалитета. Текст се може користити и као алат за учење. Туторијали и видео-упутства веома су популарни на YouTube-у, а текст се често користи да нагласи кораке и упутства. Гледалац види шта треба да уради, али текст остаје на екрану дуже него што траје изговарање, што гледаоцу омогућује да се фокусира на задатак уместо да покушава да запамти шта треба да уради. Интралингвални титлови се користе и за оно што се зове „лирик-видео“, тренд који музичке снимке повезује са караоке-снимцима. Једино што се приказује на екрану је текст песме у ритму у ком се пева, слично караоке-снимцима. Један од првих оваквих снимака био је снимак за Си Ло Гринову песму Fuck You. Текст се може користити и за анотације и рекламе. Анотације омогућују корисницима да додају текст и линкове на снимак. Најчешће се користе да мотивишу гледаоце да се претплате на канале, одгледају следећи снимак или „лајкују“ онај који гледају. Постоји могућност додавања банер-рекламе, што је један од начина како корисници могу да зараде од својих снимака. Банери се појављују на дну снимка, неки од њих се могу искључити искључивањем функције анотација, али на неке је потребно кликнути да би се искључили. ${ }^{8}$

Титлови се могу додати на било који снимак на YouTube-y, на шта званична страница за подршку и мотивише кориснике, саветујући им да „отворе свој садржај за ширу публику, укључујући и гледаоце оштећеног слуха или оне који говоре друге језике ${ }^{\prime 9}$. Додатна корист од титловања снимака на YouTube-у крије се у томе што је транскрипт укључен у резултате интернет-претраге. Фахради наводи њихову могућу употребу у сврху претраге. Наиме, све већа понуда видео садржаја, конкретно титлованих ҮouТube-снимака, суочава конзументе са бескрајном количином података, којима је могуће приступити само путем напредне семантичке мултимедијалне претраге и посеб-

ибид: 10-12.

YouTube Help. Google. 2016. Web. 11.08.2016. 
не технологије управљања како би се пронашло неколико игала у гигантском пласту сена. Већина претраживача онлајн видео-снимака поседује опцију претраге по кључној речи, при чему лексичка двосмисленост природног језика често води у непрецизне и нетачне резултате. Стога Фахради препоручује претрагу која укључује и анализу титлова. ${ }^{10}$

Титлови могу бити „затворени“ и „отворени“. Отворени титлови се увек виде и није могуће искључити их, док затворене титлове гледалац сам може укључивати и искључивати. ${ }^{11}$ „ЗЗатворени титлови шаљу позитиван сигнал претраживачу за боље разумевање садржаја - и повратну информацију за резултате претраге дате фразе, тачније за оне дуже." ${ }^{\prime 2}$ Приликом гледања снимка, опција укључивања титла се може изабрати у подешавањима која укључују и квалитет снимка и укључивање реклама. Ако снимак укључује титлове, испод се појављује иконица „СC“ („closed caption“).

YouTube је створио једноставан процес за титловање снимака, како једноставним интерфејсом тако и функцијом за захтевање превода. Корисник има опцију да тражи превод који може да плати или да пошаље позивнице личним контактима. Званична страница подршке упућује кориснике и на екстерне услуге програма за титловање снимака на YouTube-у. Титлови се могу додати и успомоћ технологије препознавања гласа, која, међутим, често резултира погрешним преводима. Један такав пример Данкис проналази у снимку корисника pewdiepie, у коме је фраза I freakin' love Fridays преведена као African Fridays. ${ }^{13}$ И поред бројних истраживања, технологија препознавања гласа још увек оставља велики простор за усавршавање, али је несумњиво од велике помоћи када је у питању транскрипција говора, па су повремене грешке углавном занемарљиве.

У употреби титлова на YouTube-у се, у нешто мањој мери него на

10 Farhadi, Babak. Enriching Subtitled YouTube Media Fragments via Utilization of the WebBased Natural Language Processors and Efficient Semantic Video Annotations. Global Journal of Science, Engineering and Technology Issue 14. 2013: 41.

11 What is the difference between open and closed captioning? University of Washington. 2016. Web. 11.08.2016.

12 Marshall, Carla. Closed Captions: The Quickest Win on YouTube. State of Digital. 2012. Web. 11.08.2016.

13 Dankis, Sofia. Subtitling the Internet. An investigation into subtitles for dynamic media. Master thesis. Stockholm: Institute for Interpretation and Translation Studies, Department for Swedish Language and Multilingualism. 2014: 12-13. 
платформи Amara додуше, огледа принцип партиципаторске културе. Један корисник не може додати тилове на снимак другог корисника, али их може послати на преглед. Корисник на једноставан начин може затражити ову услугу, а ширина интернета му омогућује да досегне даље од професионалаца који би ту услугу наплатили. Опција ослањања на волонтерски рад и допринос фанова отворена је како приватним грађанима, тако и професионалним компанијама. ${ }^{14}$

\section{Amara}

Amara је интернет-сервиси софтверски инструментзадодавање текста, титлова и превода на било који видео на интернету. До њеног појављивања, овакве услуге су биле ограничене затвореним, централизованим и скупим системима, који су за кориснике надасве исцрпљујући. Атага-систем представља отворену, прилагодљиву, флексибилну колаборативну платформу, која омогућује максимално искоришћавање „краудсорсинга“ ангажовањем волонтера. Ово је прва велика, отворена платформа са потенцијалом да велике количине видео-снимака учини доступним путем високо квалитетног титловања. ${ }^{15}$

Према Јансену, Amara се фокусира на пет важних области:

1. Једноставно коришћење -У поређењу са другим алаткама за титловање, почетници се лакше навикавају на коришћење ове платформе. Поврх тога, титловање је одвојено од видео-хостинга, што такође поједностављује процедуру.

2. Контрола квалитета - Транспарентност, одговорност и политика отвореног учешћа, према принципу сличном „Википедији“, омогућују висок квалитет титлова.

3. Компатибилност - Amara подржава употребу четири најпопуларнија хостинг-сајта (Youtube, Dailymotion, Kaltura и Vimeo), као и формате попут .mp4 и .webm.

4. Једноставна интеграција - Ову платформу је лако интегрисати на сајтове који користе неки од компатибилних видео-хостова.

14 Ибид: $12-13$.

15 Jansen, Dean, Aleli Alcala, Francisco Guzman. Amara: A Sustainable, Global Solution for Accessibility, Powered by Communities of Volunteers. International Conference on Universal Access in Human-Computer Interaction. Springer International Publishing. 2014: 401. 
5. Волонтерско ангажовање - До 2014. године забележено је стотине хиљада корисника ове платформе, као и пораст овог броја. ${ }^{16}$

Најпознатији пројекат ове платформе представља титловање видео-снимака конференција TED Talks. У оквиру овог пројекта, који још увек траје, преведено је преко 29.000 видео снимака на укупно преко 40 језика уз помоћ 25.000 волонтера. Јансен даје оквирне бројке како за овај, тако и за друге велике пројекте титловања у оквиру платформе Amara.

\begin{tabular}{|l|l|l|l|}
\hline Организација & \multicolumn{1}{|c|}{ Снимци } & \multicolumn{1}{|c|}{ Волонтери } & \multicolumn{1}{c|}{ Језици (просек) } \\
\hline TED talks & $29.000+$ & 25.000 & $\begin{array}{l}40+\text { TED Talk } \\
10+\text { језици ca TEDx и TED Ed Talks }\end{array}$ \\
\hline Udacity & 11.000 & $1.500+$ & $10+$ \\
\hline Github & 34 & $450+$ & $8-9$, неки и до 17 \\
\hline Epic Rap & 18 & 3.295 & $40+$, неки и до 60 \\
\hline
\end{tabular}

Коришћење софтвера за титловање платформе Amara изузетно је једноставно и прилагођено просечном кориснику рачунара. Најпре је потребно унети линк ка снимку који корисник жели да титлује. Након тога, уколико то неко већ није учинио раније, потребно је транскрибовати снимак на оригиналном језику. Саветује се да се транскрибују и сви пратећи звуци, како би и особе са оштећеним слухом могле да доживе снимак што је аутентичније могуће. Сама транскрипција захтева три корака: записивање, синхронизацију и ревизију. Записивање подразумева куцање текста и његово одвајање у редове. Синхронизација се обавља тако што се снимак емитује од почетка, а притиском стрелице на доле одређујемо који ред титла треба да се емитује у ком тренутку. Током ревизије гледамо снимак са већ подешеним титловима и исправљамо евентуалне неусаглашености или словне грешке. Потом корисник бира језик на који ће преводити транскрипт и превођење може да почне.

Када је у питању дужина или трајање титлова и други стандарди и прописи за уређивање титлова, Amara даје следеће смернице:

16 ибид: 402-403.

17 ибид: 408. 
- дужина реда у титлу - око 42 карактера, избегавати више од 2 реда по титлу;

- минимално трајање - титл не треба да траје краће од 1 секунде;

- $\quad$ максимално трајање - титлови дужи од 7 секунди треба да буду подељени на два;

- брзина читања - 8-25 карактера у секунди, 8-16 карактера у секунди за децу;

- звукови - треба описати смислене звукове који су релевантни за радњу, пример: (вода капље);

- музика - описати релевантну музику која нема релевантан текст, пример: (иез музика);

- идентификација говорника - треба употребљавати парентезу ради указивања на говорника којег не видимо на екрану, пример: (Мајкл) Чекајте мене $!^{18}$

Интересантно је упоредити ове смернице са смерницама које се односе на телевизијско титловање, а потичу махом са краја 20. и почетка 21. века. ${ }^{19}$ Препоручена дужина телевизијског титла од 36 карактера нешто је краћа од горенаведених смерница највероватније због разлика у форматима. Занимљиво је да аутори смерница за телевизијско титловање као брзину читања одраслих процењују 12 карактера у секунди, а деце 9 карактера у секунди. Када упоредимо то са горенаведеним смерницама, чини се да су се способности брзог читања титлова последњих година повећале, што можемо повезати са навикавањем великог броја корисника интернета на паралелно гледање видео-снимака и читање одговарајућих титлова.

18 Amara Support Center. Amara. 2016. Web. 23.08.2016.

19 Пајић, Биљана. Untertiteln als Art der audiovisuellen Übersetzung am Beispiel der Untertitelung vom Zeichentrickfilm, Felidae'. Masterarbeit. Филолошки факултет Универзитета у Београду. Београд. 2013: 6. 


\section{Предности и недостаци отвореног приступа у аудио-визуелном превођењу}

Отворени приступ у аудио-визуелном превођењу отвара мноштво могућности и има разне позитивне аспекте. Главни међу њима је свакако доступност садржаја видео-снимака широкој публици. То је управо основна идеја платформе Amara, нарочито када је у питању превођење снимака са научном тематиком, конференцијских говора и других садржаја који имају за циљ преношење знања, идеја и информација.

Доступност је, макар у случају титлова на мрежи YouTube, додано појачана и проширена већ поменутом претраживошћу текста титлова. (в. 7-8. стр.) Могућност укључивања текста титла у претрагу омогућује много већу доступност видео-снимка, него што је то случај са снимцима који немају такву опцију. Оваква опција допуњује или чак замењује функцију тзв. „хештегова“ (енг. hashtag) и самим тим постаје мултифункционална.

Поред доступности и претраживости садржаја, отворени приступ по принципу платформе Amara омогућује и одличан квалитет превода утолико што су преводи подложни провери и изменама од стране других корисника, па је, чак и када се сусретнемо са неисправним преводом, могуће да га сами изменимо и допунимо, као што то може учинити било који други регистровани члан. Међутим, колико ова опција може бити добра и корисна, толико се може и злоупотребити на различите начине. Ипак, из досадашњег искуства се на платформи Amara ово готово и не догађа, а уколико се и догоди, за сваки превод постоји протокол о изменама, времену када су учињене и члану који их је унео, па је могуће проверити који корисник је злоупотрбио могућност измене превода. Не постоји, међутим, опција да се злоупотреба пријави, што сугерише на могућност да се овакве непријатности нису до сад ни догађале, или бар не довољно често да опција пријављивања администратору постане неопходна.

Платформа Amara је препознала још једну важну предност оваквог система, па је покренула и свој корпус, који је већ стигао до верзије 1.4. У питању је мултилингвални корпус који покрива широк спектар образовних предавања. Ови ресурси су веома вредни за 
изградњу система машинског превођења образовног материјала. Говорна и образовна природа података доводи до нових изазова како за превод, тако и за евалуацију. Поврх тога, мултилингвална природа овог корпуса може имати многе друге примене попут препознавања језика, генерисања билингвалног речника итд. ${ }^{20}$

Вероватно најпроблематичнији недостатак отвореног приступа у аудио-визуелном превођењу је већ поменута злоупотреба, на неколико различитих начина. Наиме, често се догађа да корисници оваквих сајтова и платформи примећују да телевизије користе ове титлове у комерцијалне сврхе, тј. преузимају их и прилагођавају својим програмима. Платформа Amara има јасно дефинисана правила по том питању тако што не одговара за тачност превода, одриче се права на интелектуалну својину и строго забрањује њихово копирање, употребу и дистрибуцију у комерцијалне сврхе. ${ }^{21}$ Чак и сајтови који се баве искључиво омогућавањем корисницима да дистрибуирају своје титлове, попут сајта titlovi.com позивају на поштовање права преводилаца. ${ }^{22}$

Злоупотреба може, међутим, подразумевати и промоцију нежељеног садржаја у оквиру титлова, попут линкова за различите сајтове, а титлови могу бити погрешно превођени тенденциозно, са намером да се садржај филма прикаже на другачији начин. Ипак, као што је горе објашњено (в. 12. стр), платформа Amara се за сада не суочава са оваквим проблемима, док YouTube ово решава тако што само корисник који је поставио снимак може да одобри титлове. Ипак, из искуства са платформом Wikipedia, која је најбољи пример коришћења отвореног приступа знању, овакве проблеме је најбоље предупредити ефикасном контролом и заштитом.

Други већи недостатак отвореног приступа односи се на колаборативну природу краудсорсинга, која може довести до упитног квалитета превода. Наиме, онолико колико овакви преводи могу бити добри, иста толика је и могућност да буду лоши, јер приступ коришћењу

20 Abdelali, Ahmed, Francisco Guzman, Hassan Sajjad, Stephan Vogel. The AMARA Corpus: Building Parallel Language Resources for the Educational Domain. LREC. Vol. 14. 2014: 1861. Amara Terms of Service. Amara. 2013. Web. 29.08.2016.

22 Naš stav - druga strana medalje. Titlovi. 2015. Web. 29.08.2016. 
има свако ко има приступ интернету. Чак и ако особа која преводи има добру намеру и ако искључимо горепоменуту могућност злоупотребе, увек се поставља питање квалификација, било да се ради о граматичким, лексичким и правописним знањима или стручним компетенцијама уколико је у питању специфична терминологија.

Das schöne Gefühl entsteht, dass nur die Menschheit gemeinsam das wahre menschliche Wesen sein kann und, dass das Individuum nur dann froh und glücklich sein kann, wenn es den Mut hat, sich als Ganzes zu fühlen.

\section{J.W. von Goethe}

Појмови отвореног приступа и краудсорсинга већ су се поприлично одомаћили у свакодневици интернет-корисника, а показују капацитет да кроје пословну и научну будућност.

Када је у питању аудио-визуелно превођење, уз напредак на пољу технологије препознавања говора, отворени приступ и краудсорсинг отварају могућност да ускоро готово сваки онлајн-видео буде доступан у сваком делу света са интернет-конекцијом на локалном језику. На YouTube-у се сваке секунде погледа 131.546 видео-снимака ${ }^{23}$, што је сасвим довољан показатељ у којој мери је доступност садржаја видео-снимака важна.

Платформа Amara је ову важност препознала и кроз своје пројекте већ доприноси овом циљу, како по питању доступности аудио-визуелних превода, тако и по питању корпуса који ствара. Иако доступност свих видео-снимака на локалним језицима звучи утопијски, тренутно се чини да је само питање времена и технолошког напретка док ово не постане макар делимично могуће.

\section{Списак литературе}

Abdelali, Ahmed, Francisco Guzman, Hassan Sajjad, Stephan Vogel. The AMARA Corpus: Building Parallel Language Resources for the Educational Domain. LREC. Vol. 14. 2014.

$23 \quad$ Internet Live Stats. Real Time Statistics Project. 2016. Web. 30.08.2016. 
Amara Support Center. Amara. 2016. Web. 23.08.2016.

Amara Terms of Service. Amara. 2013. Web. 29.08.2016.

Budapest Open Access Initiative. Budapest Open Access Initiative. 2002. Web. 09.08.2016.

Burgess, Jean and Joshua Green. YouTube: online video and participatory culture. Cambridge: Malden. 2009

Dankis, Sofia. Subtitling the Internet. An investigation into subtitles for dynamic media. Master thesis. Stockholm: Institute for Interpretation and Translation Studies, Department for Swedish Language and Multilingualism. 2014

Duden. Bibliographisches Institut GmbH. 2016. Web. 11.08.2016.

Estellés-Arolas, Enrique, and Fernando González-Ladrón-de-Guevara. Towards an integrated crowdsourcing definition. Journal of Information Science XX (X) pp. 1-14. The Author(s) 2012: 9-10. Web. 11.08.2016.

Farhadi, Babak. Enriching Subtitled YouTube Media Fragments via Utilization of the WebBased Natural Language Processors and Efficient Semantic Video Annotations. Global Journal of Science, Engineering and Technology Issue 14. 2013

Internet Live Stats. Real Time Statistics Project. 2016. Web. 30.08.2016.

Jansen, Dean, Aleli Alcala, Francisco Guzman. Amara: A Sustainable, Global Solution for Accessibility, Powered by Communities of Volunteers. International Conference on Universal Access in Human-Computer Interaction. Springer International Publishing. 2014

Marshall, Carla. Closed Captions: The Quickest Win on YouTube. State of Digital. 2012. Web. 11.08.2016.

Naš stav - druga strana medalje. Titlovi. 2015. Web. 29.08.2016.

Oxford Dictionaries. Oxford University Press. 2016. Web. 11.08.2016.

Пајић, Биљана. Untertiteln als Art der audiovisuellen Übersetzung am Beispiel der Untertitelung vom Zeichentrickfilm, Felidae'. Masterarbeit. Филолошки факултет Универзитета у Београду. Београд. 2013.

Suber, Peter. Open Access. Cambridge, London: MIT Press. 2012: 7. Web. 09.08.2016.

What is the difference between open and closed captioning? University of Washington. 2016. Web. 11.08.2016.

YouTube Help. Google. 2016. Web. 11.08.2016. 


\section{Biljana Pajić \\ University of Belgrade \\ Faculty of Philology}

\section{OPEN SOURCE PRINCIPLES IN AUDIOVISUAL TRANSLATION}

\section{Summary}

Open source principles play a more and more important role in virtual culture. Many scientists support open source information in science and many other experts adopt this kind of attitude in their fields. Open source principles in audiovisual translation, i.e. in subtitling videos from famous online portals, is a relatively new occurrence. In which way are open source principles possible in audiovisual translation? Which are their advantages, disadvantages and challenges? What kind of future is there to expect? These are the questions that this paper tries to answer through examples of platforms such as YouTube and Amara.

Key words: audiovisual translation, open source, subtitling, Internet, Amara, YouTube 